[Agr. Biol. Chem., Vol. 32, No, 6, p. 794 795, 1968]

\title{
Diffusable Bitter Peptides in Peptic Hydrolyzate of Soybean Protein
}

Partial hydrolysis of soybean protein by some proteolytic enzyme proved to be effective in removing unfavorable flavor components from soybean protein. ${ }^{11}$ However, bitter peptides were produced through the enzymic hydrolysis, which inhibited positive food uses of the soybean protein hydrolyzate. Although several reports on bitter peptides derived from dairy products and enzymic hydrolyzate of casein were presented, the relationship between peptide structure and bitterness was not fully elucidated en $^{2-61}$ Furthermore, no reports concerning structural studies on diffusable bitter peptides have been known. Most parts of bitter peptides in peptic hydrolyzate of soybean protein were diffusable and estimated to be less than 1500 in molecular weight from gel permeation chromatography. The present paper deals with isolation, amino acid sequences, and structural characteristics of the diffusable bitter peptides.

Cold-insoluble protein of soybean was prepared by the method of Briggs and Mann." Ten $g$ of the cold-insoluble protein in 4 liters of dilute $\mathrm{HCl}(\mathrm{pH} 1.6)$ was hydrolyzed with $0.1 \mathrm{~g}$ of pepsin (Sigma, 1:60,000, recrystallyzed) at $37^{\circ} \mathrm{C}$ for $24 \mathrm{hr}$. The resulting hydrolyzate was dialyzed against 10 fold

1) M. Fujimaki, H. Kato, S. Arai and E. Tamaki, Food Technol., in press.

2) C. W. Raadsveld, Intern. Dairy Congr., Proc. 13th (Hague), 2, 676 (1953).

3) J. W. Carr, T. C. Loughheed, and B. E. Baker, J. Sci. Food Agr., 7, 629 (1956).

4) K. Ichikawa, T. Yamamoto, and J. Fukumoto, J. Agr. Chem. Soc. Japan, 33, 1044 (1959).

5) D. F. Gordon, Jr. and M. L. Speck, Appl. Microbiol., 13, 537 (1965).

6) V.R. Harwalkar and J.A. Elliott, J. Dairy Sci., 48, 784 (1965).

7) D. R. Briggs and R. L. Mann, Cereal Chem., 27, $243(1950)$. volume of water at $4^{\circ} \mathrm{C}$ for $72 \mathrm{hr}$. The diffusate was fractionated through Sephadex G-10 using water as a solvent, and through Dowex 50(w)-X2 (pyridinium) using pyridineacetic acid stepwise eluting method of Guidotti et al. ${ }^{8)}$ Bitter peptides thus obtained were purified further by thin layer chromatography of silica gel $\mathrm{G}$ (Merck) using $n$-butanolacetic acid-water $(4: 1: 2)$. Through these procedures were isolated 7 bitter peptides that were completely homogeneous according to thin layer chromatograms of these peptides and to those of DNP-peptides. Amino acid compositions were determined, after azeotropic $\mathrm{HCl}$ hydrolysis at $110^{\circ} \mathrm{C}$ for $20 \mathrm{hr}$ or $105^{\circ} \mathrm{C}$ for $16 \mathrm{hr}$, with the aid of the Hitachi model KLA-3B amino acid analyzer. Presence of tryptophan and S-containing amino acids was denied by examining ultraviolet spectrum of tryptophan, and cysteic acid and/or methionine sulfoxide formation by azeotropic $\mathrm{HCl}$ hydrolysis, respectively. $\mathrm{N}$-Terminal amino acids were determined by 2, 4-DNP method of Sanger and Thompson "and C-terminal amino acids, together with probable sequences of amino acids near the C-terminals, were determined by the carboxypeptidase A method of Fraenkel-Conrat et al. ${ }^{10}$ "The structures of diffusable bitter peptides were proposed as follows: $\mathrm{H} \cdot \mathrm{Gly}-\mathrm{Leu} \cdot \mathrm{OH}(\mathrm{I}), \mathrm{H} \cdot \mathrm{Leu}-\mathrm{Phe} \cdot \mathrm{OH}$ (II), H.Ser-Lys-Gly-Leu-OH (III), H.LeuLys.OH (IV), H.Phe-(Ile, Leu $\left.{ }_{2}\right)$-Gln-Gly-Val . $\mathrm{OH}(\mathrm{V}), \mathrm{H} \cdot \mathrm{Arg}-\mathrm{Leu}-\mathrm{Leu} \cdot \mathrm{OH}(\mathrm{VI})$, and $\mathrm{H}$.

8) G. Guidotti, R. J. Hill, and W. Konigsberg, J. Biol. Chem., 237, 2184 (1962).

9) F. Sanger and E. O.P. Thompson, Biochem. J., 53, 353 (1953).

10) H. Fraenkel-Conrat, J.I. Harris, and A. L. Levy, "Method of biochemical analysis", Vol. II, ed. by D. Glick, Interscience Publishers, New York, N. Y., 1955, p. 359. 
Arg-Leu. $\mathrm{OH}$ (VII). Serine- $\beta-O$ in peptide-III was not in bound state because free serine was liberated by exhaust hydrolysis of this peptide by a bacterial neutral proteinase (Nagarse, 1,500,000 P. U. N. in vial, lyophilized and crystallyzed). Lysine- $--N$ in peptideIII or IV was not also in bound state because only $\varepsilon-N$-DNP-lysine was detected by acid hydrolysis of DNP-peptide-III or IV. $\delta$-COOH of glutamic acid in peptide- $V$ was in state of acid amide because glutamine was liberated by the bacterial proteinase hydrolysis of the peptide.

It is remarkable that each diffusable bitter peptide obtained here has leucine as a $\mathrm{N}$ - or C-terminal amino acid, with the exception of peptide- $\mathrm{V}$ which, considering the substrate specificity of pepsin, may be an intermediate product in peptic hydrolysis.
This research has been financed in part by a grant made by the United States Department of Agriculture under P. L. 480, Project No. UR-All-(40)-8.

The authors wish to express their thanks to Dr. John C. Cowan of Northern Utilization Research Division, USDA, for his helpful guidance throughout this work, and to Professor Yosito Sakurai of the Japan Womens' University for his interest.

Masao Fujimaki

Michiko Yamashita

Yukio Okazawa

Soichi AraI

Department of Agricutural Chemistry, The University of Tokyo,

Bunkyo-ku, Tokyo 